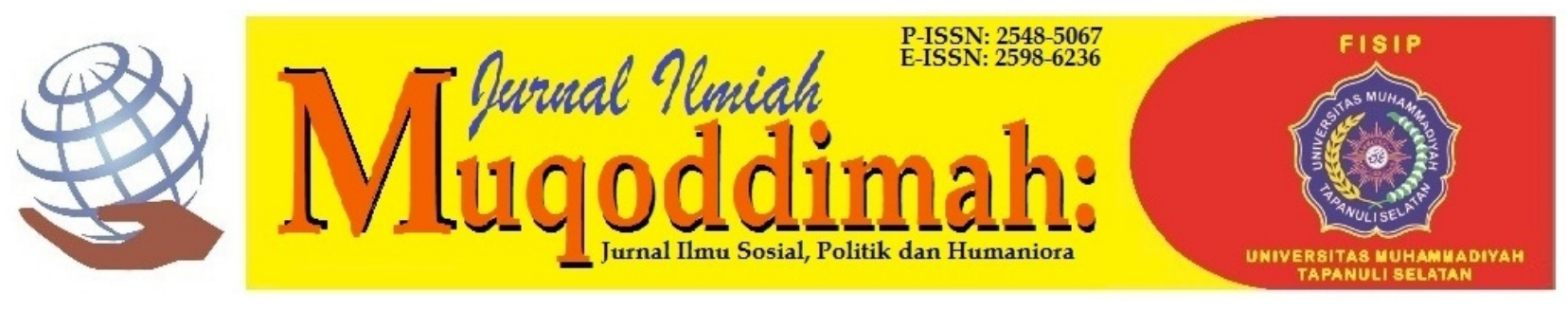

\title{
Mengkaji Implementasi Kebijakan Dana Kelurahan Dalam Pemberdayaan Masyarakat
}

\author{
Kadek Tirtanadi 1), Ida Bagus Teddy Prianthara ${ }^{2)}$ \\ Program Studi Administrasi Publik, Universitas Pendidikan Nasional 1) \\ Program Studi Manajemen, Universitas Pendidikan Nasional ${ }^{2)}$ \\ Jalan Waturenggong No.164 Panjer, Denpasar, Bali, Indonesia ${ }^{1,2)}$ \\ kadektirtandi.id@gmail.com ${ }^{1)}$ \\ gusteddy@undiknas.ac.id ${ }^{2)}$
}

\begin{abstract}
Abstrak
Dukungan pendanaan untuk kelurahan dari alokasi APBN melalui Dana Alokasi Umum (DAU) Tambahan disambut antusias oleh kelurahan. Dan diharapkan mampu memenuhi pendanaan kelurahan, mengingat sebelumnya terjadi fenomena kesenjangan antara desa dengan kelurahan. Tujuan penelitian adalah untuk mengkaji implementasi kebijakan dana kelurahan berdasarkan pendekatan implementasi menurut teori dari George C. Edward III. Dalam proses penelitian ini, menggunakan metode deskriptif dan pendekatan secara kualitatif. Hasil penelitian menunjukkan bahwa Implementasi Kebijakan Dana Kelurahan di Kecamatan Buleleng sudah cukup baik, dan berdasarkan analisis faktor yang mempengaruhi implementasi dengan pendekatan implementasi menurut George C. Edward III, indikator Komunikasi, Disposisi dan Struktur Birokrasi dalam Implementasi Kebijakan Dana Kelurahan sudah cukup baik, sedangkan indikator sumberdaya masih belum memenuhi karena masih adanya keterbatasan sumberdaya manusia dan sarana prasarana di Kelurahan. Faktor pendukung implementasi kebijakan dana kelurahan adalah adanya partisipasi masyarakat dan adanya kerjasama antar pelaksana kebijakan. Sedangkan faktor penghambat adalah sikap atau respon masyarakat dan sumberdaya manusia pelaksana. Dampak dengan adanya implementasi kebijakan dana kelurahan sangat positif dan dirasakan oleh masyarakat berdasarkan hasil pelaksanaan kegiatan pembangunan sarana dan kegiatan pemberdayaan yang langsung menyentuh masyarakat, seperti adanya perbaikan infrastruktur dan penyediaan sarana dan prasarana penunjang untuk kepentingan masyarakat kelurahan.
\end{abstract}

Kata kunci: implementasi, dana kelurahan, pemberdayaan

\begin{abstract}
Funding support for sub-districts from the APBN allocation through the Additional General Allocation Fund (DAU) was enthusiastically welcomed by the kelurahan. And it is hoped that it will be able to meet the village's funding, given the previous phenomenon of the gap between the village and the sub-district. The purpose of the study was to examine the implementation of the village fund policy based on the implementation approach according to the theory of George C. Edward III. In the process of this research, using descriptive methods and qualitative approaches. The results showed that the implementation of the Village Fund Policy in Buleleng District was quite good, and based on the analysis of the factors that influenced the implementation with the implementation approach according to George C. Edward III, the indicators of Communication, Disposition and Bureaucratic Structure in the Implementation of the Village Fund Policy were quite good, while the indicators resources still do not meet because there are still limited human resources and infrastructure in the village. The supporting factors for implementing the village fund
\end{abstract}


policy are community participation and cooperation between policy implementers. Meanwhile, the inhibiting factor is the attitude or response of the community and the implementing human resources. The impact of the implementation of the village fund policy is very positive and felt by the community based on the results of the implementation of facilities development activities and empowerment activities that directly touch the community, such as infrastructure improvements and the provision of supporting facilities and infrastructure for the benefit of the village community.

Keywords: implementation, village funds, empowerment

\section{PENDAHULUAN}

Pembangunan dilakukan secara berkelanjutan sejatinya dilakukan untuk memperbaiki keadaan masa lampau dan masa kini untuk mencapai keadaan tertentu yang lebih baik pada masa mendatang. Alasan suatu negara melakukan pembangunan berkelanjutan merupakan upaya untuk memperbaiki kesejahteraan dan taraf hidup masyarakat adalah serta melanjutkan kekurangan pencapaian pembangunan di masa sebelumnya. Dalam konteks bernegara, pemerintah hadir terdepan dalam menjamin kemakmuran seluruh lapisan warga masyarakatnya. Pemerintah harus bisa membuat kebijakan-kebijakan dalam proses pembangunan nasional yang bermanfaat strategis, karena semakin kedepan kebutuhan warga masyarakat semakin banyak dan permasalahan kehidupan masyarakat juga seiring semakin kompleks.

Lahirnya Undang-Undang Nomor 23 Tahun 2014 tentang Pemerintahan Daerah semakin memberikan ruang dan memperkuat kedudukan daerah dalam melaksanakan otonomi yang seluas-luasnya untuk mengelola secara mandiri kepentingan daerah. Tujuan utamanya adalah terjadinya pemerataan kesejahteraan masyarakat di setiap daerah melalui pelayanan yang optimal, pemberdayaan yang tepat sasaran, dan peran aktif serta masyarakat dalam pembangunan daerah. Otonomi daerah pada hakekatnya adalah cara untuk menghadirkan pelayanan yang lebih dekat kepada masyarakat. Kebijakan-kebijakan pemerintah daerah dalam mengelola potensi dan masyarakatnya, diharapkan mampu mengakomodir kepentingan masyarakat daerah.

Dapat kita cermati kondisi sampai saat ini, bahwa penyelenggaraan kehidupan bernegara, jika kita melihat dinamika pembangunan dan penyelenggaraan pemerintahan daerah pasca reformasi dan otonomi daerah, masih menemui berbagai permasalahan dan tantangan didalam proses pelaksanaann tugas dan kewenangan daerah guna mendukung upaya mewujudkan kepemerintahan yang baik di daerah. Banyak hal yang menjadi sandungan dalam implementasi otonomi daerah. Beberapa hal yang masih kita dapat dilihat adalah bagaimana pelayanan ke masyarakat belum sepenuhnya merata menyentuh seluruh lapisan masyarakat terbawah, dan masih ditemukan disparitas tingkat pembangunan antara daerah perkotaan dengan pedesaan.

Kelurahan sebagai salah satu bagian organisasi pemerintahan di wilayah perkotaan yang berada di garis terbawah dan berhadapan langsung dengan masyarakat merupakan unsur penting keberhasilan pembangunan daerah perkotaan khususnya dalam implementasi kebijakan daerah. Dikatakan sebagai unsur penting karena kelurahan berhadapan langsung dengan masyarakat, oleh karena itu kelurahan harus mampu menjadi tempat dalam menampung aspirasi dan keinginan bagi masyarakat untuk disalurkan kepada pemerintah daerah. Perubahan kedudukan kelurahan pasca berlakunya ketentuan perundang-undangan yang mengatur tentang Pemerintahan Daerah, bahwa kelurahan merupakan perangkat kecamatan. Kedudukan kelurahan diatur lebih lanjut dalam Peraturan Pemerintah Nomor 17 Tahun 2018 tentang Kecamatan, disebutkan kelurahan adalah perangkat Kecamatan. Kelurahan yang dipimpin oleh lurah, dalam kedudukannya sebagai perangkat kecamatan, fungsi dan tugas utama kelurahan adalah melaksanakan penyelenggaraan pemerintahan dalam cakupan wilayah Kelurahan.

Sebagai penyelenggara pemerintahan dalam melayani kepentingan masyarakat, melaksanakan pembangunan dan kemasyarakatan bukan merupakan tugas yang mudah 
dilaksanakan oleh kelurahan. Kelurahan dan desa berbeda dari segi kedudukan namun merupakan sama-sama lembaga yang berada di garis terdepan dan merupakan unsur terpenting dalam penyelenggara pelayanan yang bersentuhan langsung dengan masyarakat. Namun, belakangan ini terdapat fenomena kesenjangan yang dirasakan oleh masyarakat yang berada di Kelurahan. Hal ini disebakan karena adanya kecemburuan terhadap desa, selama ini desa memperoleh anggaran dari Pemerintah Pusat sejak Tahun 2015, dengan anggaran dan kewenangan yang dimiliki desa, mampu menggeliatkan pembangunan desa. Sedangkan anggaran kelurahan setiap tahunnya yang merupakan bagian dari Anggaran Pendapatan dan Belanja Daerah (APBD) Kabupaten/Kota cenderung dirasakan masih minim jika dibandingkan dengan tugas pokok kelurahan dalam menyelenggarakan pelayanan masyarakat, pembangunan sarana dan memberdayakan masyarakat. Fenomena kesenjangan antara desa dan kelurahan ini tidak hanya menjadi perhatian di Bali, bahkan sudah dirasakan hampir disemua daerah. Imbas atas kesenjangan ini, tidak hanya sebatas sikap masyarakat saja, namun beberapa fenomena yang terjadi di suatu daerah, sudah muncul prakarsa masyarakat yang cenderung menginginkan perubahan status dari kelurahan menjadi desa karena alasan perolehan anggaran.

Pemerintah pusat juga menyadari jika kesenjangan antara kelurahan dan desa bila tidak diantisipasi bisa menimbulkan tensi semakin meningkat dalam masyarakat. Hal ini juga yang mendasari kebijakan pengalokasian dana untuk kelurahan yang berasal dari anggaran belanja pemerintah pusat. Inisiasi pemerintah dalam memberikan dukungan pendanaan untuk kelurahan diduga karena ada kesenjangan antara kelurahan dan desa. Dalam keterangannya dalam sebuah media, Menteri Keuangan Sri Mulyani menegaskan bahwa ketimpangan dalam postur anggaran memicu adanya kondisi yang tendensius di sejumlah tempat. Karena desa selama ini sudah mendapatkan penganggaran dari pemerintah, namun kelurahan belum memperoleh anggaran sama sekali (sumber: https://Bisnis.com.)

Pada Tahun 2019, pemerintah pusat mengeluarkan kebijakan pengalokasian sejumlah anggaran yang ditujukan untuk mendukung skema pendanaan pada kelurahan, sebagaimana hal ini untuk memenuhi pendanaan kelurahan sesuai dengan ketentuan dalam peraturan pemerintah yang mengatur tentang kecamatan. Kebijakan penganggaran ini dalam bentuk pengalokasian Dana Alokasi Umum (DAU) Tambahan. Pengalokasian dana kelurahan melalui sekema DAU Tambahan ini sudah termuat dalam undang-undang melalui tentang Anggaran Pendapatan dan Belanja Negara (APBN) Tahun 2019. Pemerintah mengalokasikan anggaran dalam bentuk transfer DAU Tambahan ke daerah khusus untuk pendanaan kelurahan sebesar Rp3.triliun untuk kelurahan di seluruh daerah. Selanjutnya, untuk melaksanakan lebih lanjut ketentuan pemberian anggaran DAU tersebut, mekanisme tata cata penyaluran DAU Tambahan ini lebih rinci diatur melalui Peraturan Menteri Keuangan (PMK), dalam hal ini diatur dalam PMK Nomor: 187/PMK.07/2018 tentang Tata Cara Penyaluran Dana Alokasi Umum Tambahan Tahun 2019.

Kebijakan dana kelurahan melalui mekanisme DAU Tambahan ini, baru dimulai sejak Tahun Anggaran 2019, sehingga merupakan pertama kali dilaksanakan oleh kelurahan pada tahun tersebut. Oleh sebab itu kebijakan ini tentu berpotensi mengalami persoalan dan hambatan-hambatan dalam pelaksanannya. Perlu adanya kesiapan yang matang dalam melaksanakan suatu kebijakan jika ingin mencapai tujuan yang maksimal. Berdasarkan sifat atau karakteristik kebijakan, menurut pendapat Edwards III dalam Anggara (2014:149) diungkapkan bahwa ada beberapa jenis kebijakan yang pada dasarnya mudah menemui permasalahan dalam pengimplementasiannya, salah satunya disebutkan adalah new policies yakni kebijakan yang baru atau kebijakan yang belum pernah dilaksanakan.

Penelitian tentang implementasi kebijakan dana kelurahan sudah pernah dilakukan oleh berbagai kalangan sebelumnya. Beberapa kesimpulan penelitian mengungkapkan masih adanya permasalahan-permasalahan dalam implementasi dana kelurahan. Penelitian sebelumnya yang dilakukan oleh Yuliastri, Henny dkk (2020), diungkapkan bahwa dalam pengelolaan dana 
kelurahan kadang terjadi penyerapan anggaran yang kurang optimal yang disebabkan pada tahap pelaksanaan kegiatan, khususnya kegiatan fisik, terbatasnya waktu sehingga menyebabkan anggaran tidak dapat diproses untuk dicairkan. Peneliti Tobing, Artha Lbn. (2019) dalam penelitiannya menyimpulkan bahwa pengelolaan dana kelurahan yang bersumber dari anggaran Kabupaten/kota cenderung belum optimal digunakan untuk mewujudkan pembangunan dan pertumbuhan kelurahan. Sementara hasil penelitian lainnya, diungkap oleh Prasetyo, Zahnudin Nurhidayatullah Dwi dkk (2014) yang menunjukkan hasil penelitian, bahwa dalam pelaksanaanya implementasi dana kelurahan masih kurang penggunaannya untuk pengembangan pada bidang sosial ekonomi masyarakat.

Jumlah kelurahan di Provinsi Bali yang berada pada 8 kabupaten/kota sebanyak 80 Kelurahan. Adapun jumlah kelurahan paling banyak yakni dengan 19 kelurahan berada di Kabupaten Buleleng dibandingkan dengan Kabupaten/Kota lainnya.

Tabel 1.

Pagu Dana Kelurahan Berdasarkan Kabupaten/Kota di Bali yang Bersumber Dari DAU Tambahan Tahun 2019

\begin{tabular}{c|c|c|c|c}
\hline No & Kabupaten & Kategori & $\begin{array}{c}\text { Pagu Anggaran DAU } \\
\text { Tambahan Per } \\
\text { Kelurahan }\end{array}$ & $\begin{array}{c}\text { Jumlah } \\
\text { Kelurahan }\end{array}$ \\
\hline 1 & Badung & Baik & Rp 352,941,000 & 16 \\
2 & Bangli & Perlu Ditingkatkan & Rp 370,138,000 & 4 \\
3 & Buleleng & Baik & Rp 352,941,000 & 19 \\
4 & Gianyar & Baik & Rp 352,941,000 & 6 \\
5 & Jembrana & Perlu Ditingkatkan & Rp 370,138,000 & 10 \\
6 & Karangasem & Baik & Rp 352,941,000 & 3 \\
7 & Klungkung & Baik & Rp 352,941,000 & 4 \\
8 & Denpasar & Baik & Rp 352,941,000 & 16 \\
\hline \multicolumn{7}{r}{ Total } & & 80
\end{tabular}

Sumber: PMK No. 187/PMK.07/2018

Tabel 1 menunjukkan besaran dana kelurahan yang diterima yang berasal dari DAU Tambahan tidaklah sama tiap kelurahan di tiap kabupaten, karena tedapat kriteria utama dalam menentukan besaran DAU Tambahan bagi daerah yaitu berdasarkan hasil pengkategorian daerah yang sudah ditentukan Kementerian. Adapun rincian besaran dana kelurahan per kelurahan pada kabupaten/kota di Bali berdasarkan kategori daerah serta jumlah kelurahan berdasarkan kabupaten/kota. 
Gambar 1.

Besaran Total Alokasi Anggaran DAU Tambahan

Tahun 2019 di Provinsi Bali per Kabupaten/Kota

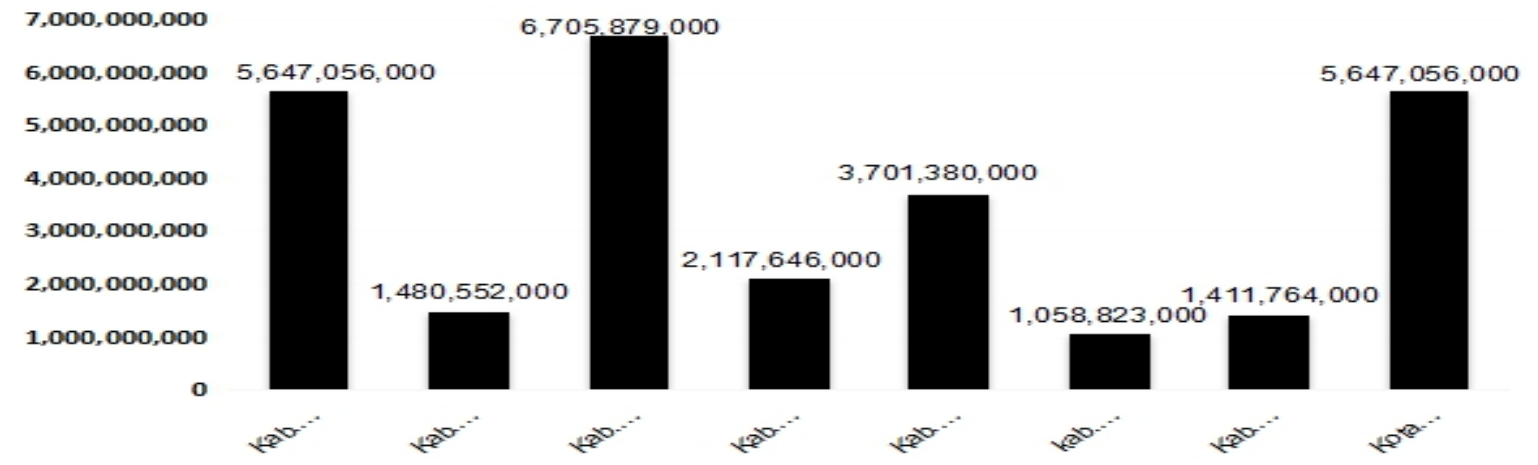

Sumber: Data diolah berdasarkan PMK No. 187/PMK.07/2018

Grafik pada gambar 1. menunjukkan perbandingan akumulasi pagu alokasi anggaran DAU Tambahan yang diterima oleh masing-masing kabupaten/kota se-Bali. Berdasarkan grafik tersebut, dapat diketahui secara akumulasi Kabupaten Buleleng menerima alokasi anggaran DAU Tambahan dari pusat untuk kelurahan dengan jumlah terbesar di Provinsi Bali dibandingkan dengan kabupaten/kota lainnya.

Berdasar pada penjelasan latar belakang, penulis mengadakan penelitian tentang implementasi kebijakan dana kelurahan dalam pemberdayaan masyarakat, untuk mengetahui bagaimana implementasi kebijakan dana kelurahan, mengetahui faktor pendukung dan penghambat serta dampak dari kebijakan dana kelurahan.

\section{METODE}

Dalam proses penelitian ini, metode yang digunakan adalah metode deskriptif dengan pendekatan kualitatif. Lokasi pelaksanaan penelitian ini dilakukan pada Kelurahan Astina, Kelurahan Kampung Anyar, dan Kelurahan Banyuning di Kecamatan Buleleng, Kabupaten Buleleng. Informan penelitian ditentukan secara purposive sampling, adapun informan utama pada penelitian ini adalah Camat Buleleng, Lurah Astina, Lurah Kampung Anyar dan Lurah Banyuning. Pengumpulan data dilakukan dengan interview/wawancara mendalam serta dokumentasi data-data yang berhubungan dengan fokus penelitian. Analisis data dilakukan melalui reduksi data yaitu merangkum data hasil penelitian, kemudian data yang diperoleh disajikan dengan menghasilkan narasi-narasi kualitatif, selanjutnya ditarik suatu kesimpulan.

\section{HASIL DAN PEMBAHASAN}

Implementasi kebijakan dana kelurahan menjadi satu kesatuan dalam pengelolaan kegiatan utama kelurahan yaitu pembangunan pada bidang sarana-prasarana maupun pemberdayaan masyarakat. Adapun dasar ketentuan pengelolaan kegiatan di Kelurahan diatur dalam Permendagri No. 130 Tahun 2018 tentang Kegiatan Pembangunan Sarana dan Prasarana Kelurahan dan Pemberdayaan Masyarakat. Selanjutnya menindaklanjuti Permendagri tersebut, Menteri Dalam Negeri mempertegas lagi dengan mengeluarkan Surat Edaran (SE) Mendagri No.146/2694/SJ sebagai petunjuk dalam pelaksanaan ketentuan Permendagri tersebut dan menjadi acuan daerah dalam memepersiapkan, melaksanakan dan menyelesaikan kegiatan-kegiatan pada tingkat kelurahan.

Secara umum, pelaksanaan kegiatan di kelurahan yaitu pada bidang sarana dan prasarana maupun bidang kegiatan pemberdayaan terdiri dari tahap perencanaan, pelaksanaan kegiatan, penatausahaan dan pelaporan, dan pembinaan pengawasan (binwas). Pada tahap 
perencanaan, lurah bersama Lembaga Pemberdayaan Masyarakat (LPM) melakukan musyawarah pembangunan dengan melibatkan lembaga kemasyarakatan lainnya seperti, Posyandu, Pemberdayaan Kesejahteraan Keluarga (PKK), Rukun Tangga (RT), tokoh masyarakat, kelompok masyarakat dan perwakilan masyarakat untuk menyepakati kegiatan yang akan dibiayai dari DAU Tambahan maupun sumber anggaran lainnya. Hasil dari musyawarah mendapatkan skala prioritas kegiatan berdasarkan usulan prioritas masyarakat baik dibidang sarana dan prasarana maupun bidang pemberdayaan masyarakat, namun kesepakatan penentuan kegiatan mengacu isi rencana pembangunan jangka menengah Kabupaten Buleleng, yang dituangkan melalui rencana strategis perangkat daerah dalam hal ini kecamatan. Selanjutnya dilakukan penyusunan anggaran kelurahan melalui kegiatan penyusunan rencana anggaran oleh pihak kecamatan berdasarkan usulan kegiatan dari kelurahan mengacu pada hasil muyawarah di kelurahan.

Pelaksanaan kegiatan, merupakan tahapan eksekusi anggaran sesuai jenis kegiatan yang telah disusun dalam daftar pelaksanaan anggaran. Lurah sebagai Kuasa Pengguna Anggaran (KPA) mengkoordinir pelaksanaan pengelolaan keuangan dan kegiatan bersama dengan Pejabat Pelaksana Teknis Kegiatan (PPTK), Pejabat Penatausahaan Keuangan (PPK) Pembantu, dan Bendahara Pengeluaran Pembantu (BPP). Dalam melaksanakan kegiatan lurah didukung oleh kepala lingkungan, lembaga pemberdayaan masyarakat dan lembaga kemasyarakatan lainya untuk melaksanakan program sesuai jenis kegiatan baik di bidang sarana prasarana maupun pemberdayaan masyarakat. Dalam pelaksanaan kegiatan di Kelurahan Astina, Kelurahan Banyuning dan Kelurahan Kampung Anyar cenderung dilaksanakan dengan secara swakelola. Hal ini memberikan keuntungan tersendiri, karena kelurahan dapat menggunakan tenaga kerja berasal dari warga masyarakat sekitar. Imbasnya kelurahan dapat memberdayakan masyarakat sekitar dan masyarakat sekitar merasa diuntungkan karena dapat diuntungkan dari sisi ekonomi karena mendapat penghasilan dengan adanya pelibatan dalam pelaksanaan kegiatan.

Berdasarkan penelitian menunjukkan bahwa pada Kelurahan Astina, Kelurahan Banyuning, dan Kelurahan Kampung Anyar sudah melaksanakan kegiatan mengacu berdasarkan daftar pelaksanaan anggaran yang telah disusun sebelumnya, dan salah satunya anggaran tersebut berasal dari alokasi dana DAU Tambahan yang diterima kelurahan pada Tahun Anggaran 2019. Anggaran direalisasikan untuk 2 program utama yaitu pembangunan dan pemberdayaan. Rincian realisasi anggaran dan kegiatan yang bersumber dari DAU Tambahan Tahun 2019 di Kelurahan Astina.

Tabel 2.

Realisasi Anggaran yang bersumber dari DAU Tambahan Tahun 2019 di Kelurahan Astina

\begin{tabular}{llcccc}
\hline No & Program/Kegiatan & $\begin{array}{c}\text { Anggaran } \\
\text { Dana DAU } \\
\text { Tambahan } \\
\text { (Rp) }\end{array}$ & $\begin{array}{c}\text { Realisasi } \\
\text { (Rp) }\end{array}$ & $\begin{array}{c}\text { Sisa } \\
\text { Anggaran } \\
(\mathbf{R p})\end{array}$ & $\begin{array}{c}\text { Persentase } \\
\text { realisasi } \\
\text { Anggaran } \\
(\%)\end{array}$ \\
\hline 1 & $\begin{array}{l}\text { Pembangunan Sarana } \\
\text { dan Prasarana }\end{array}$ & $276,415,000,-$ & $276,415,000,-$ & - & 100 \\
& $\begin{array}{l}\text { Kelurahan } \\
\text { Pemberdayaan } \\
\text { Masyarakat di Kelurahan }\end{array}$ & $76,526,000$ & $76,526,000$. & - & 100 \\
\hline
\end{tabular}

Sumber: Data Diolah Dari Dokumen Penelitian 
Dilihat dari uraian Tabel 2 diatas, dapat dijelaskan bahwa Anggaran DAU Tambahan sebesar Rp352,941,000,- yang terbagi menjadi 2 program utama pembangunan dan pemberdayaan yaitu untuk kegiatan sarana prasarana sebesar Rp276,415,000,- dan untuk kegiatan pemberdayaan masyarakat sebesar Rp76,526,000,-, sudah terealisasi secara fisik maupun keuangan $100 \%$. Adapun jenis kegiatan yang terealisasi tersebut tersaji seperti pada tabel 3 di bawah ini:

Tabel 3.

Realisasi Pelaksanaan Kegiatan dari dana DAU Tambahan di Kelurahan Astina T.A. 2019

\begin{tabular}{cllcc} 
No & $\begin{array}{c}\text { Program/ } \\
\text { Kegiatan }\end{array}$ & \multicolumn{1}{c}{ Jenis Kegiatan } & Output & Satuan \\
\hline 1 & Pembangunan & Tempat Sampah & 60 & unit \\
& Sarana dan & Biopori & 20 & unit \\
& prasarana & Tabung Pemadam Kebakaran & 2 & unit \\
& & Konstruksi Jalan Beton & 1 & paket \\
& & Konstruksi Drainase & 1 & paket \\
& & Gerobak Sampah & 2 & Unit \\
& & Kegiatan Pembinaan Sekaa & 1 & kegiata \\
2 & Pemberdayaan & Gong & & $\mathrm{n}$ \\
\hline
\end{tabular}

Sumber: Data Diolah Dari Dokumen Penelitian

Pengelolaan dana di Kelurahan Banyuning, juga menunjukan hasil yang cukup baik dengan mampu diselesaikannya kegiatan baik secara fisik maupun keuangan. Adapun realisasi anggaran dan program/kegiatan yang bersumber dari DAU Tambahan di Kelurahan Banyuning seperti tersaji pada Tabel 4 berikut ini:

Tabel 4.

Realisasi Anggaran yang bersumber dari

DAU Tambahan Tahun 2019 di Kelurahan Banyuning

\begin{tabular}{cccccc}
\hline No & Program/Kegiatan & $\begin{array}{c}\text { Anggaran } \\
\text { Dana DAU } \\
\text { Tambahan } \\
\text { (Rp) }\end{array}$ & $\begin{array}{c}\text { Realisasi } \\
\text { (Rp) }\end{array}$ & $\begin{array}{c}\text { Sisa } \\
\text { Anggaran } \\
\text { (Rp) }\end{array}$ & $\begin{array}{c}\text { Persentase } \\
\text { realisasi } \\
\text { Anggaran } \\
\text { (\%) }\end{array}$ \\
\hline 1 & $\begin{array}{l}\text { Pembangunan Sarana } \\
\text { dan Prasarana }\end{array}$ & $287,415,000 .,-$ & $287,415,000,-$ & - & 100 \\
$\begin{array}{l}\text { Kelurahan } \\
2\end{array}$ & $\begin{array}{l}\text { Pemberdayaan } \\
\text { Masyarakat di Kelurahan }\end{array}$ & $65,526,000 .-$ & $65,526,000 .$. & - & 100 \\
\hline
\end{tabular}

Sumber: Data Diolah Dari Dokumen Penelitian

Berdasarkan tabel 4, menunjukkan bahwa dari total anggaran Kelurahan Banyuning yang bersumber dari DAU Tambahan sebesar Rp352,941,000,- untuk kegiatan sarana prasarana sebesar Rp287,415,000.,- dan untuk kegiatan pemberdayaan masyarakat sebesar Rp65,526,000,-, sudah terealisasi penuh dengan total presentase realisasi $100 \%$. Jenis kegiatan yang dilaksanakan melalui anggaran tersebut ditampilkan pada tabel 5 berikut dibawah ini. 
Tabel 5.

Realisasi Pelaksanaan Kegiatan dari dana

DAU Tambahan di Kelurahan Banyuning T.A. 2019

\begin{tabular}{|c|c|c|c|c|}
\hline No & $\begin{array}{l}\text { Program/ } \\
\text { Kegiatan }\end{array}$ & Jenis Kegiatan & Output & Satuan \\
\hline \multirow[t]{6}{*}{1} & Pembangunan & Tempat Sampah & 60 & unit \\
\hline & Sarana dan & Biopori & 20 & unit \\
\hline & prasarana & Meja Kerja Posyandu & 22 & buah \\
\hline & & Kursi Kerja Posyandu & 44 & buah \\
\hline & & Konstruksi Jalan beton & 2 & paket \\
\hline & & Konstruksi Drainase & 2 & paket \\
\hline \multirow[t]{2}{*}{2} & Pemberdayaan & Bimbingan Teknis Pengelolaan & 1 & kegiata \\
\hline & Masyarakat & Sampah & & \\
\hline
\end{tabular}

Sumber: Data Diolah Dari Dokumen Penelitian

Sedangkan pengelolaan dana kelurahan di Kelurahan Kampung Anyar sudah terlaksana dalam 2 program utama, namun demikian anggaran tidak seluruhnya terealisasi karena masih ada sisa anggaran dari pelaksanaan kegiatan pemberdayaan masyarakat. Berikut realisasi pelaksanaan anggaran dan program yang bersumber dari DAU Tambahan Tahun 2019 di Kelurahan Kampung Anyar seperti ditampilkan pada tabel 6 berikut ini:

Tabel 6.

Realisasi Anggaran bersumber dari dana

DAU Tambahan Tahun 2019 di Kelurahan Kampung Anyar

\begin{tabular}{cccccc}
\hline No & Program/Kegiatan & $\begin{array}{c}\text { Anggaran } \\
\text { Dana DAU } \\
\text { Tambahan } \\
(\mathbf{R p})\end{array}$ & $\begin{array}{c}\text { Realisasi } \\
\mathbf{( R p )}\end{array}$ & $\begin{array}{c}\text { Sisa } \\
\text { Anggaran } \\
\mathbf{( R p )}\end{array}$ & $\begin{array}{c}\text { Persentase } \\
\text { realisasi } \\
\text { Anggaran } \\
(\%)\end{array}$ \\
\hline 1 & $\begin{array}{l}\text { Pembangunan Sarana } \\
\text { dan Prasarana }\end{array}$ & $160.000 .000 .,-$ & $160.000 .000,-$ & - & 100 \\
$\begin{array}{l}\text { Kelurahan } \\
\text { Pemberdayaan } \\
\text { Masyarakat di Kelurahan }\end{array}$ & $192,941,000 .-$ & $140.865 .478 .$. & $52,075,522$ & $73 \%$ \\
\hline
\end{tabular}

Sumber: Data Diolah Dari Dokumen Penelitian

Tabel 6 menunjukkan dari total anggaran dana kelurahan di Kampung Anyar yang bersumber dari DAU Tambahan sebesar Rp352,941,000,- untuk kegiatan sarana dan prasarana sebesar Rp160.000.000.,- sudah terealisasi 100\% dan untuk kegiatan pemberdayaan masyarakat sebesar Rp192.941.000,- teralisasi Rp140.865.478, masih ada sisa anggaran sebesar Rp52,075,522,-. Pemanfaatan anggaran untuk kegiatan sarana dan prasarana dan pemberdayaan masyarakat ditampilkan melalui tabel 7 di bawah ini. 
Tabel 7.

Realisasi Pelaksanaan Kegiatan dari dana DAU Tambahan di Kelurahan Kampung Anyar T.A. 2019

\begin{tabular}{|c|c|c|c|c|}
\hline No & $\begin{array}{l}\text { Program/ } \\
\text { Kegiatan }\end{array}$ & Jenis Kegiatan & Output & Satuan \\
\hline \multirow[t]{6}{*}{1.} & Pembangunan & Pemeliharaan Got & 1 & paket \\
\hline & Sarana dan & Tempat Sampah & 60 & unit \\
\hline & prasarana & Biopori & 20 & unit \\
\hline & & Konstruksi Jalan Paving & 1 & paket \\
\hline & & Konstruksi Drainase & 1 & paket \\
\hline & & Gerobak Sampah & 2 & \\
\hline \multirow[t]{9}{*}{2.} & Pemberdayaan & Bimtek Pengelolaan Sampah & 1 & Keg. \\
\hline & Masyarakat & Pentas Tarian Rejang & 1 & Keg. \\
\hline & & Kegiatan Posyandu & 1 & Keg. \\
\hline & & Gong Anak-anak & 1 & Keg. \\
\hline & & $\begin{array}{l}\text { Kegiatan Pembinaan Muda } \\
\text { Mudi }\end{array}$ & 1 & Keg. \\
\hline & & pembinaan Sekaa Santi & 1 & Keg. \\
\hline & & Kegiatan PKK & 1 & Keg. \\
\hline & & Pembinaan Gong Wanita & 1 & Keg. \\
\hline & & Pelatihan Bencana Alam & 1 & Keg. \\
\hline
\end{tabular}

\section{Sumber: Data Diolah Dari Dokumen Penelitian}

Dalam proses penatausahaan keuangan di Kelurahan, PPTK melakukan eksekusi kegiatan sesuai anggaran dan didukung oleh bendahara bengeluaran pembantu. PPK Pembantu melakukan verifikasi pertanggungjawaban atas pelaksanaan kegiatan yang disampaikan oleh Bendahara pengeluaran pembantu kepada Lurah. Laporan pelaksanaan kegiatan dan realisasi anggaran yang bersumber dari dana kelurahan disampaikan oleh Lurah kepada Bupati melalui camat. Kecamatan selaku Organisasi Perangkat Daerah (OPD) leading dari Kelurahan mendapatkan delegasi dari Bupati dalam melakukan pembinaan serta pengawasan atas pelaksanaan kegiatan-kegiatan di kelurahan. Bentuk pembinaan dan pengawasan dilaksanakan melalui fasilitasi, konsultansi kepada Kelurahan. Kecamatan juga melakukan pembinaan berupa pendampingan langsung kepada kelurahan dalam penyelesaian kegiatan.

Berdasarkan pada penjelasan diatas menunjukkan bahwa pelaksanaan kebijakan dana kelurahan di Kecamatan Buleleng, Kabupaten Buleleng sudah dilaksanakan mengikuti ketentuan peraturan, kemudian realisasi kegiatan dan anggaran dana kelurahan yang bersumber dari DAU tambahan menunjukkan kegiatan sudah terlaksana dengan baik. Disamping melihat implementasi kebijakan dana kelurahan berdasarkan hasil pelaksanaan kegiatan mulai dari perencanaan, pelaksanaan, pelaporan dan pembinaan/pengawasan, untuk mengetahui bagaimana tingkat keberhasilan implementasi kebijakan dana kelurahan itu, penulis juga menganalisis faktor yang berpengaruh dalam implementasi dengan pendekatan implementasi dari teori George C. Edward III dalam Anggara (2014:248-254) yaitu empat faktor yang dapat mempengaruhi dalam pencapaian tingkat keberhasilan implementasi yaitu faktor komunikasi, sumber daya, disposisi dan struktur birokrasi.

Komunikasi, dalam hal ini adanya kegiatan dalam bentuk sosialisasi kebijakan yang dilakukan oleh Kecamatan beserta perangkat daerah lainnya dalam menginformasikan isi kebijakan dana kelurahan kepada kelurahan selaku implementor, sudah berjalan dengan baik. Selanjutnya pihak kelurahan juga sudah mensosialisasikan kebijakan dana kelurahan kepada 
semua jajaran kelurahan. Begitu juga kejelasan informasi yang diterima terkait kebijakan dana kelurahan sudah baik.

Indikator sumberdaya dalam pelaksanaan kebijakan dana kelurahan masih kurang. Tekait kondisi sumberdaya, bahwa sumber daya manusia di kelurahan rata-rata masih kurang baik dari segi kuantitas dan kapasitas, sehingga perlu sekali penataan pegawai kelurahan dan peningkatkan kapasitas pegawai. Meskipun sudah pernah diberikan bimbingan teknis, namun masih kurang. Sedangkan, sumberdaya sarana juga masih belum memadai, berdasarkan hasil wawancara dan pengamatan di lapangan, kelurahan memmerlukan sarana lebih, untuk menjalankan program kegiatan dan pelaksanaan pelayanan.

Disposisi, bahwa terkait faktor disposisi atau sikap pelaksana dalam implementasi kebijakan dana dapat dikatakan sudah berjalan baik. Hal ini juga didukung oleh fakta tentang komitmen dan upaya-upaya nyata yang sudah dilaksanakan oleh kelurahan dan jajarannya dalam mengelola dana kelurahan melalui kegiatan pembangunan baik pada bidang sarana maupun pemberdayaan masyarakat. Selain itu respon positif kelurahan ditunjukkan dengan adanya kerjasama yang baik dari pelaksana sehingga kegiatan dapat terkelola dan terlaksana dengan cukup baik.

Ditinjau dari indikator struktur birokrasi, pelaksanaan kebijakan dana kelurahan sudah mempedomani ketentuan sebagaimana diatur dalam Permendagri No. 130 Tahun 2018 dan Surat Edaran Mendagri. Ketentuan ini sebagai pedoman utama pelaksanaan kegiatan di kelurahan dan cukup mampu diterapkan mualai tahap perencanaan, pelaksanaan kegiatan, penatausahaan dan pelaporan, dan pembinaan pengawasan. Selain pedoman kerja, indikator struktur birokrasi juga sudah baik dilihat dari mekanisme pembagian tugas kerja dan tanggungjawab yang sudah berjalan, didukung juga oleh adanya kerjasama antar pelaksana dikelurahan.

Kegiatan-kegiatan di Kelurahan dapat terlaksana karena adanya dukungan masyarakat baik dalam perencanaan, pelaksanaan dan pengawasan kegiatan. Selain itu adanya jalinan Kerjasama antar pelaksana kegiatan di kelurahan maupun dengan pihak kecamatan. Hambatan dalam pelaksanaan kebijakan dana kelurahan secara umum disebabkan faktor sumberdaya manusia di kelurahan itu sendiri. Sedangkan terkadang adanya sikap dan respon masyarakat yang kurang antusias dengan kegiatan di kelurahan.

Kebijakan dana kelurahan ini membawa dampak positif bagi pembangunan kelurahan. Dimana hasil-hasil kegiatan dapat menyentuh langsung masyarakat sebagai sasaran kebijakan. Berbeda dengan tahun-tahun sebelumnya dengan adanya dana kelurahan ini, kegiatan pembangunan semakin menggeliat. Imbas positif dari kebijakan dana kelurahan mampu mewujudkan: a). Adanya perbaikan infrastruktur di lingkungan kelurahan seperti perbaikan jalan pemukiman, perbaikan drainase pemukiman dan tersedianya sarana dan prasarana penunjang untuk kepentingan masyarakat kelurahan antara lain sarana pengelolaan sampah bagi masyarakat.b). Dari perspektif pemberdayaan, implementasi kebijakan dana kelurahan telah mendorong upaya pemberdayaan masyarakat secara langsung antara lain melalui pelibatan tenaga kerja di kelurahan dalam pelaksanaan kegiatan dan melalui pelaksanaan kegiatan posyandu, kegiatan PKK, kegiatan pelatihan/bimbingan teknis dan pembinaan terhadap kelompok-kelompok masyarakat.

\section{SIMPULAN DAN SARAN Simpulan}

Dari penjelasan hasil penelitian serta pembahasan, dapat diuraikan kesimpulan dalam penelitian ini sebagai berikut:

1. Implementasi Kebijakan Dana Kelurahan Dalam Pemberdayaan Masyarakat di Kecamatan Buleleng sudah cukup baik, hal ini dapat dijelaskan berdasarkan pencapaian hasil pelaksanaan program/kegiatan dan realisasi anggaran sudah dapat terselesaikan dengan baik. Hasil analisis implementasi kebijakan yang dilakukan berdasarkan faktor yang 
mempengaruhi implementasi menurut George C. Edward III bahwa Implementasi Kebijakan Dana Kelurahan dapat dikatakan sudah memenuhi indikator Komunikasi, Disposisi dan Struktur Birokrasi, sedangkan indikator sumberdaya masih belum terpenuhi karena masih adanya keterbatasan dalam sumberdaya manusia dan sarana prasarana di Kelurahan.

2. Faktor pendukung implementasi kebijakan dana kelurahan adalah adanya partisipasi masyarakat dan adanya kerjasama antar pelaksana kegiatan di Kelurahan. Sedangkan faktor yang dapat menghambat adalah sikap atau respon masyarakat dan sumberdaya manusia pelaksana.

3. Dampak dari implementasi kebijakan dana kelurahan sangat positif dan dirasakan oleh masyarakat berdasarkan hasil pelaksanaan kegiatan baik pembangunan sarana dan prasarana maupun pemberdayaan yang langsung menyentuh masyarakat, melalui: a). Adanya perbaikan infrastruktur di lingkungan kelurahan seperti perbaikan jalan/gang pemukiman, perbaikan drainase pemukiman dan tersedianya sarana dan prasarana penunjang untuk kepentingan masyarakat kelurahan antara lain sarana pengelolaan sampah bagi masyarakat. b). Dari perspektif pemberdayaan, implementasi kebijakan dana kelurahan telah mendorong upaya pemberdayaan masyarakat secara langsung antara lain, pelibatan tenaga kerja di kelurahan dalam pelaksanaan kegiatan, dan melalui pelaksanaan kegiatan posyandu, kegiatan PKK, kegiatan pelatihan/bimbingan teknis dan pembinaan terhadap kelompok-kelompok masyarakat.

\section{Saran}

Melihat hasil penelitian, saran penulis adalah sebagai berikut:

1. Kecamatan selaku OPD leading kelurahan agar lebih mengoptimalkan dalam melaksanakan monitoring dan evaluasi pelaksanaan pengelolaan dana kelurahan, sehingga kegiatan dan anggaran yang telah disusun dalam daftar pelaksanaan anggaran semua dapat dilaksanakan oleh kelurahan.

2. Perlunya dukungan dari pemerintah Kabupaten dalam upaya peningkatkan kapasitas pegawai di kelurahan melalui penataan pegawai dan pelatihan-pelatihan serta pembinaan yang lebih intensif terhadap pegawai di kelurahan dan dukungan sarana dan prasarana kantor untuk kelancaran pelaksanaan tugas-tugas di kelurahan.

\section{UCAPAN TERIMAKASIH}

Ungkapan terimakasih yang sebesar-besarnya penulis ucapkan kepada pihak-pihak yang mendukung penuh pelaksanaan penelitian ini yaitu kepada Camat Buleleng beserta jajaran, Lurah Astina beserta seluruh perangkat, Lurah Banyuning berserta seluruh perangkat, dan Lurah Kampung Anyar berserta seluruh perangkat kelurahan, yang telah sedia mendukung kelancaran pelaksanaan penelitian baik dalam meluangkan waktu untuk memberikan pendapat, informasi serta memberikan data dukung terkait penelitian.

\section{DAFTAR PUSTAKA}

Aida, N.A. dan Ervita Luluk Zahara. 2018. Dana Kelurahan dan Tantangannya. Buletin APBN. Vol. III, Edisi 21, November 2018. Pusat Kajian Anggaran Badan Keahlian DPR RI.

Anggara, Sahya. (2014). Kebijakan Publik. Bandung: Pustaka Setia.

Aswar. (2017). Implementasi Kebijakan Pengelolaan Alokasi Dana Desa Di Desa Siboang Kecamatan Sojol Kabupaten Donggala. 100 e Jurnal Katalogis, Volume 5 Nomor 12, Desember 2017, hIm. 99-107

Batubara, Lucie Deviredtravia. (2016). Implementasi Program Generasi Berencana (Genre) Pada Remaja Sekolah Di Kota Medan. Tesis, Universitas Sumatera Utara, Medan

Djiko, Richard, Putra Sian Arimawa dan Charles H.S. Tangkau. (2018). Implementasi Kebijakan Jaminan Kesehatan Nasional Di Kabupaten Halmahera Utara. PUBLISIA: Jurnal Ilmu Administrasi Publik, Volume 3, Nomor 2, Oktober 2018

Hardani dkk. 2020. Metode Penelitian Kualitatif dan Kuantitatif. Yogyakarta: Pustaka IImu 
Handoyo, Eko. 2012. Kebijakan Publik. Semarang: Widya Karya.

Lahagu, Dennis Baktian. (2016). Implementasi Kebijakan Stelsel Aktif Pada Pelayanan Administrasi Kependudukan Di Dinas Kependudukan Dan Catatan Sipil Kabupaten Nias. Tesis, Universitas Sumatera Utara, Medan

Maryani, Dedeh dan Ruth Roselin E. Nainggolan. 2019. Pemberdayaan Masyarakat. Yogyakarta: Deepublish.

Mulyawan, Rahman. 2016. Masyarakat, Wilayah dan Pembangunan. Bandung: Unpad Press.

Mardikanto dan Soebiato. 2013. Pemberdayaan Masyarakat dalam Perspektif Kebijakan Publik. Bandung: Alfabeta.

Prasetyo, Zahnudin Nurhidayatullah Dwi dkk (2014). Implementasi Alokasi Dana Kelurahan Dalam Pemberdayaan Masyarakat Di Kelurahan Malawele Kabupaten Sorong. Vol 6, No. 2 Juli 2017

Rohaeni, Eni N. dan Oyon Saryono. (2018). Implementasi Kebijakan Program Indonesia Pintar (PIP) Melalui Kartu Indonesia Pintar (KIP) dalam Upaya Pemerataan Pendidikan. Indonesian Journal of Education Management \& Administration Review, Volume 2 Number 1. Juni 2018

Sidik. Fajar. (2014). Implementasi Kebijakan Kartu Menuju Sejahtera (KMS) Pemerintah Kota Yogyakarta di Bidang Pendidikan. Jurnal Kebijakan \& Administrasi Publik (JKAP) Vol 18, No 2, November 2014

Setyati, Rina. (2015). Implementasi Kebijakan Penataan Ruang Terbuka Hijau Kawasan Perumahan Kota Banjarbaru. Jurnal Kebijakan \& Administrasi Publik (JKAP) Vol. 19, No. 1, Mei 2015

Sugiyono. (2015). Metode Penelitian Manajemen. Bandung: Alfabeta

Tobing, Artha Lbn. (2019). Alokasi Dana Kelurahan Dalam Pembangunan Kelurahan Ditinjau Dari Segi Implementasi Kebijakan di Kelurahan Tangkahan Martubun. Jurnal Stindo Profesional Vol V No.3, Mei 2019

Yuliastri, Henny dkk (2020). Pengelolaan Alokasi Dana Kelurahan Studi: Analisis Kebijakan Pengelolaan Dana Kelurahan Untuk Pemberdayaan Masyarakat Di Kecamatan Banjarmasin Tengah Kota Banjarmasin. Thesis, Universitas Islam Kalimantan MAB 